\title{
STUDY OF THE CHARACTERISTICS OF PLASMA SPRAY SEALING ALUMINUM- SILICON-POLYESTER COATINGS
}

\author{
Mrdak R. Mihajlo \\ IMTEL Institute od Microwave Techniques and Electronics, \\ Belgrade
}

FIELS: Chemical Technology

DOI: 10.5937/vojtehg1203071M

ARTICLE TYPE: Original Scientific Paper

\section{Summary:}

This study shows the homologation of the plasma spray parameters of soft abrasive AlSi - Polyester seals so that they can be applied on the TV2 117 A compressor engines. The research has aimed at substituting existing sealants with a new class of materials in order to increase the sealing effect under the highest levels of pressure and to provide the air flow temperature of $100-125^{\circ} \mathrm{C}$ through the compressor. The Metco 601NS material and plasma spray technology were applied on the air labyrinth ring as a part of the TV2-117A turbojet engine compressor in order to obtain soft sealing. The deposit parameters were carefully selected in order to obtain coatings with the best characteristics depending on their application. The flow of helium was taken as a basic parameter in the parameter selection procedure. The coating with the best mechanical and structural properties was deposited on the air labyrinth ring to examine the effect of the coating application in an assembly. The microstructures of deposited layers were estimated with a light microscope and a (SEM) Scanning Electron Microscope. The microstructural analysis of deposited layers was performed according to the Pratt - Whitney standard. The assessment of the mechanical properties of the coatings was done by examining the macrohardness of the sealing layers with the HR15Y method. The coating bond strength was tested by tensile testing. The effect of the air labyrinth ring sealing was tested inside the TV2-117A engine compressor on the test station for a period of 42 hour.

Key words: atmospheric plasma spray (APS), deposition, sealing, microstructure, interface, macrohardness, bond strength.

\section{Introduction}

The development of new generations of turbo-jet engines has led to the development of new technologies and sealing materials. Nowadays, soft wear coatings, resistant to erosion and resulting in low-

Acknowledgement: The author is thankful for the financial support from the Ministry of Education and Science of the Republic of Serbia (national projects OI 174004, TR 34016). 
energy friction conditions, are applied on low and high pressure compressor components. During exploitation, soft-sealing coatings are exposed to wear instead of causing the wear of blades or labyrinth seams. Improved sealing between rotating and stationary parts in aircraft gas turbines significantly increases engine performances by improving thermal efficiency.This objective has been achieved by applying soft and hard seals in turbo-jet engines. Blades in low and high pressure compressors and gas turbines act on soft seals as lathe knives, thus keeping the gap between the rotor and the coating at the minimum. These coatings are mostly multiphase materials produced by thermal spray technology procedures. Powders for the production of soft wear coatings consist of a metal base and an additional phase which controls the amount of porosity in layers. Sealing efficiency requires a combination of properties usually optimized by a composition and a phase ratio in the mixture. Development of turbo jet engines has resulted in a growing demand for improved efficiency and greater sealing power of engines. This has led to extensive efforts to improve the performance of various components in turbo-jet engines, industrial gas turbines, compressors and generators. One of the critical areas is the clearance between the blade tip and a casing which should be reduced to a minimum in order to minimize leakage between the engine components [1-3]. In recent years, the application of modern seals on turbo-jet engines has significantly improved engine performances and sealability. Soft-wear coatings have been developed for various locations in turbines [4]. The plasma spray process is the most popular technological procedure for the productin of soft seals [4]. During operation, very complex mechanisms occur during the consumption of coating materials. This includes scraping sealant materials by blade tips, their smearing and sticking to blades, crushing, melting, erosion and oxidation [5]. During operation, sealing coatings exposed to wear must not be damaged and after being scrapped by blades they must remain smooth. Good coating wear in exploitation involves appropriate coating softness as well as sufficient coating hardness in order to resist to gas erosion due to high gas velocity and particles present in the gas. Resistance to oxidation and corrosion and resistance to thermal shock are also the key criteria which coatings exposed to wear must satisfy in engine systems. In order to meet all these requirements and allow the control of leakage between components, coatings are often composed of two or more components. Sealing coating consists of a metal base and the second phase as a solid lubricant to control wear and porosity [6]. Polyester is often used as a means to control porosity and as a solid lubricant surrounded by and enclosed in the metal base.This helps to reduce the transfer of the coating onto the blades, to reduce chipping and to prevent coating erosion.

Sealing materials used in gas turbine compressors and turbo-jet engines are subjected to a wide temperature range, from the lowest to the hig- 
hest engine operating temperatures. Among the most successful materials for sealing low and medium pressure compressors at relatively low temperatures is AlSi-polyester wear coating. The development of compositions and structures of soft sealing materials is mainly based on studies of tribological properties of coatings $[7-9,10]$, which allow to determine under what conditions coatings have the best wear characteristics $[11,12]$. This information allows an appropriate choice of a coating and a prediction of its behavior in exploitation [13]. Soft sealing coatings are suitable for eccentric assemblies and they compensate for tolerance changes caused by machining. Coatings with gaps adjustable to the minimum value improve engine performances [14].

The Metco 601NS powder is a mixture of AISi alloys and polyester which has been specially developed to control the clearance of mechanical part elements.Tests on aircraft engines have confirmed that Metco 601NS coatings have high wear resistance without causing the compressor blade tip wear, excellent resistance to oxidation up to $345^{\circ} \mathrm{C}$ and good resistance to thermal shock. The powder is designed to be deposited by the atmospheric plasma spray process (APS) using argon / hydrogen or argon / helium as plasma gases. The Metco 601NS powder is certified as a product that meets the requirements of reputable firms such as Pratt \& Whitney specification PWA1349 and Rolls Royce MSRR 9507/15, etc. The powder is recommended for sealing compressor parts where air of a certain temperature flows through and it serves as a replacement for black rubber. It can be applied to internal and external surfaces as a seal on low and high pressure compressors. Depending on the plasma spray equipment, the Metco 601NS powder produces coatings of macro hardness HR15y: $73 \pm 5,70 \pm 10$ and $70 \pm 5$. Generally, the coating macro hardness is within the limits of $60-80 \mathrm{HR} 15 \mathrm{y}$. The adhesion of coatings ranges from 6.9 to $14 \mathrm{Mpa}$, depending on the depositing parameters. Due to low bond strength values, sealing coatings are always deposited in a dual system with nickel-aluminide coating (Metco 450NS powder).Coatings contain tiny pores with a share of $3 \%$ to $5 \%$ depending on the type of equipment and plasma depositing parameters. The coatings paired with tempered steel have the coefficient of friction of 0.47 [15].

The aim of this study was to optimize the parameters of plasma spray depositing AISi - polyester powder. The research and results achieved in the world in this area were the starting point for us to homologate and apply, for the first time, the material produced in Western countries on the air labyrinth ring of the TV2-117A turbojet engine compressor produced in the East. The aim of this study was to examine the effect of sealing gaskets by plasma spray technology and a new material and to substitute existing materials. A new generation of materials was expected to provide better sealing for higher compressor efficiency with lower fuel consumption fuel. The expected effects were confirmed after 42-hour engine testing on a test stand. 


\section{Details of the experiment}

The Metco 601NS powder, Sulzer Metco, was used for the experiments. This powder is a mixture of polyester and AlSi alloy (AlSi 60\% - 40\% polyester) with a melting temperature of $425^{\circ} \mathrm{C}$ and the range of grain size of powder particles from 10 microns to 106 microns [15]. The deposited AISipolyester powder bonds well with the base. The powder manufacturer prescribes that the powder be used with its Metco (3M,7M, 9M and 10M) plasma spray systems with prescribed parameters of powder deposition; therefore, if other plasma spray systems are used, the parameters must be optimized and tested. Due to the powder low melting temperature, helium was applied since the $\mathrm{Ar} / \mathrm{He}$ combination gives a shorter and denser plasma jet of lower specific entalphy as compared to $\mathrm{Ar} / \mathrm{H}_{2}$. This allows less powder component evaporation and combustion. Also, denser plasma such as Ar-He pumps in the ambient air to a lower extent, thus avoiding powder oxidation reduction and the powder deposits with higher density packaging in the coating [16]. Due to the low melting temperature, powder coatings were also deposited at a lower intensity of electrical current and a plasma gas flow variable.The experiment used the SG - 100 Plasmadyne plasma gun with appropriate robotic control spray conditions. The plasma gun consists of: $\mathrm{K} 1083$-129 cathode, A 2083 -129 anode and GI 2083130 gas injector. In selecting the depositing parameters, the helium plasma gas flow was taken as the basic parameter. The helium gas flow must be optimal to ensure complete melting of powder particles and thereby minimize the evaporation of powder components.On the other hand, plasma gas flow rate should provide a uniform deposit of powder particles to provide continuous deposition of layers in the form of AlSi mesh that will take soften and molten polyester particles into it thus providing a uniform and homogeneous structure of the deposited layers throughout the coating cross-section. In this study, during the deposition of AlSi-polyester powder particles, two He plasma gas flows of $6 \mathrm{I} / \mathrm{min}$ and $12 \mathrm{I} / \mathrm{min}$ were used while other parameters were of constant values. The list of the used parameters is shown in Table 1.

Plasma spray parameters

Table 1

Plazma sprej parametri

Tabela 1

\begin{tabular}{|l|c|}
\hline \multicolumn{1}{|c|}{ The parameters of deposition } & Value \\
\hline Electrical current $(\mathrm{A})$ & 600 \\
\hline Arc voltage $(\mathrm{V})$ & 32 \\
\hline Primary plasma gas Ar (I/min ) & 47 \\
\hline Secondary plasma gas He (I/min) & $6 / 12$ \\
\hline Wearing powder gas Ar (I/min ) & 6 \\
\hline Flow rate of powder ( g/min ) & 50 \\
\hline Distance of the substrate $(\mathrm{mm})$ & 80 \\
\hline
\end{tabular}


Three groups of coatings were deposited. The first group of coatings was deposited with the He flow of $6 \mathrm{I} / \mathrm{min}$ and $12 \mathrm{I} / \mathrm{min}$ with a thickness of $0.5 \mathrm{~mm}$ to determine the effect of He flow on the bond macro hardness and strength. The second group of coatings was deposited with the $\mathrm{He}$ flow of $12 \mathrm{I} / \mathrm{min}$ with a layer thickness of $0.10,0.20$ and $0.30 \mathrm{~mm}$ to determine the influence of the coating thickness on the bond strength. In the third group, coatings with thicknesses from 1.6 to $2.2 \mathrm{~mm}$ prescribed for the air labyrinth ring were deposited to examine the layer microstructure. In order to analyze the fracture morphology, the coating with the best structural and mechanical properties was fractured.

The substrate material on which AISi - polyester layers were deposited was $\mathrm{X} 15 \mathrm{Cr} 13$ steel (AMS 5504). Before deposition, the substrate was not preheated and the surface was roughened with white electrocorundum of the grain size from 0.7 to $1.5 \mathrm{~mm}$. The roughening aimed to remove the thin oxide film from the substrate surface in order to obtain higher bond strength of the coating substrate. The testing and characterization of the coatings were done according to the Pratt \& Whitney standard [17].

Macro hardness was measured using the Rockwell steel balls of $12.7 \mathrm{~mm}$ in diameter with a weight of $15 \mathrm{~kg}$ (HR15y). The coating macro hardness was measured along the layers. In order to evaluate the homogeneity of the layers, the measurement was carried out in three areas: in the middle, on the left side and on the right side of the samples. The samples for the macro hardness measurement as well as for the microstructure analysis had the dimensions of $70 \times 20 \times 1.5 \mathrm{~mm}$. The shown macro hardness results are the average of multiple measurements.

The bond strength between the coating and the base was determined by tensile testing. Two samples were paired, with dimensions of $\varnothing 25 \times 50 \mathrm{~mm}$, and the coating was deposited on only one of them. The samples were glued together and left to bind, fixed in an appropriate tool. Adapters, used in the testing, were constructed to ensure the elimination of shear forces. The tests were performed on a universal hydraulic tensile testing machine at room temperature at a constant speed of $1 \mathrm{~mm} / \mathrm{min}$ [17]. Three pairs of samples were used for each group of coatings, and the obtained values were averaged.

The microstructure of coatings and the quality of the coating bond and the base were analyzed using a light microscope. The morphology of the fracture of the coating with the best characteristics was examined on the Scanning Electron Microscope (SEM).

\section{Results and discussion}

Table 2 shows the obtained values for the macro hardness and the bond strength of the AlSi-polyester coating for the layer thicknesses of $0.5 \mathrm{~mm}$, depending on the helium flow. The values of AlSi - polyester layer macro hard- 
ness are directly related to the helium flow. The layers deposited with the helium flow of $6 \mathrm{I} / \mathrm{min}$ showed lower values of macro hardness: 72HRy. The coatings deposited with the helium flow of $12 \mathrm{I} / \mathrm{min}$ showed the macro hardness value of $80 \mathrm{HRy}$. The average difference of macro hardness values between the layers was HR15y. The average macro hardness values for both coatings were within the prescribed limits [15]. The helium flow influenced the density of the layers and the ratio of AISi/polyester deposited in coatings to a lower extent. The layers deposited with a higher helium flow were thicker as confirmed by the metallographic examination of the specimens. Also, higher values of the macro hardness of the AlSi-polyester layers deposited with a greater helium flow show a higher cohesive strength of the layers, as confirmed by the results of the tensile strength testing.

Vrednosti makrotvrdoće i čvrstoće spoja slojeva AISi-poliester

Tabela 2

Table 2

Values of the macro hardness and the bond strength of AISi-polyester layers

\begin{tabular}{|c|c|c|}
\hline \multirow{2}{*}{$\begin{array}{c}\text { He Flow } \\
\text { I/min }\end{array}$} & \multicolumn{2}{|c|}{ AISi - polyester } \\
\cline { 2 - 3 } & $\begin{array}{c}\text { Macro hardness } \\
\text { HR15y }\end{array}$ & $\begin{array}{c}\text { Bond strength } \\
\text { MPa }\end{array}$ \\
\hline 6 & 72 & 10 \\
\hline 12 & 80 & 13 \\
\hline
\end{tabular}

The values of the bond strength of the AISi - polyester layers were directly related to the helium flow. The coatings deposited with the higher throughput of helium had a higher tensile strength of bonds $-13 \mathrm{MPa}$, and the layers deposited with a lower helium flow rate had the tensile bond strength of 10MPa. During the tests, fractures occurred along the coating/supstrat interface in all samples. This meant that the cohesive strength of the AISipolyester coating was good. The values of tensile bond strength were within the prescribed limits for both coatings [15]. For the second group of coatings deposited with a layer thickness of $0.10,0.20$ and $0.30 \mathrm{~mm}$ and a helium flow of 12 I / min, the values of the tensile bond strength (Fig. 1) showed a great influence of the coating thickness on the obtained values for the bond strength.The layers of thickness at $0.1 \mathrm{~mm}$ showed the highest value of the tensile bond strength of $29 \mathrm{MPa}$ as expected. During the depositing procedure, the molten powder particles input higher voltage to the layers with the increase of the coating thickness due to a larger temperature difference between the upper layers that were being deposited and the lower layers which had been already deposited. Due to a higher proportion of residual stresses in thick coatings, tensile strength was lower.The layers with a thickness of $0.2 \mathrm{~mm}$ had a strength of $23 \mathrm{MPa}$, and the layers with a thickness of $0.3 \mathrm{~mm}$ had a bond strength of $20 \mathrm{MPa}$. All the layers had the tensile bond strength higher than the prescribed values [15]. Another parameter resulting in high 
values of tensile bond strength for all the coatings is a good preparation of the surface substrate, which was confirmed by a metalographic examination of the interface between the surface substrate and the coating. The microstructures of the AlSi-polyester layers deposited with a helium flow rate of $6 \mathrm{I}$ I min are shown in Figs. 2 and 3. Both photomicrographs show a uniform mesh structure of the AISi - polyester layers. The boundaries at the interface between the substrate and the AISi layers - polyester coatings are extremely clean, which indicates a good preparation of the surface substrate.

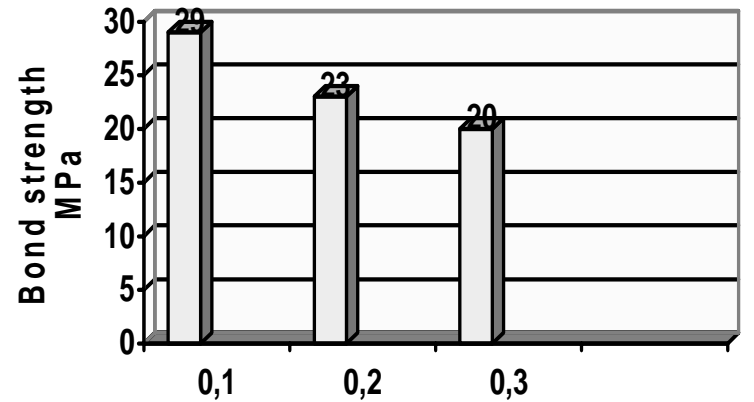

Thickness of the coating $\mathrm{mm}$

Figure 1 - Strength of the AISi-polyester layers depending on the coating thickness Slika 1 - Čvrstoća spoja AISi-poliester slojeva u zavisnosti od debljine prevlake

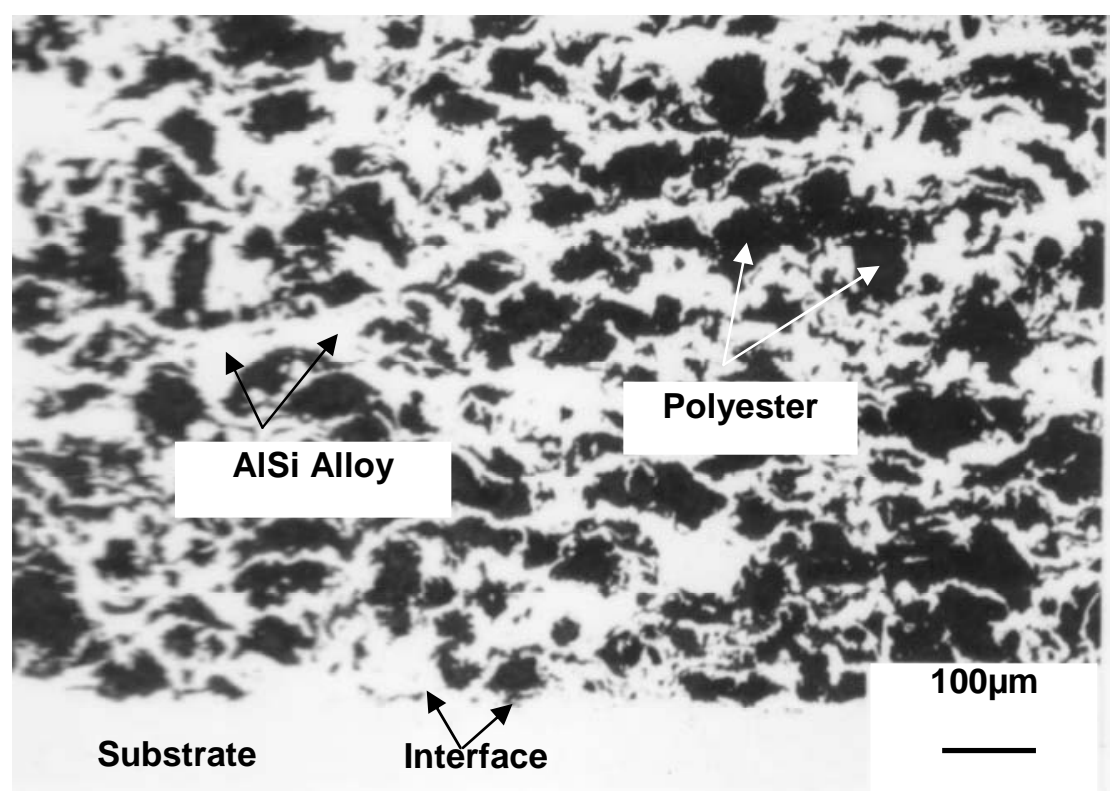

Figure 2 - Microstructure of the NiAl-polyester coatings deposited with 6 I/ min $\mathrm{He}$ Slika 2 - Mikrostruktura NiAl-poliester prevlake deponovane sa 6 I / min He 


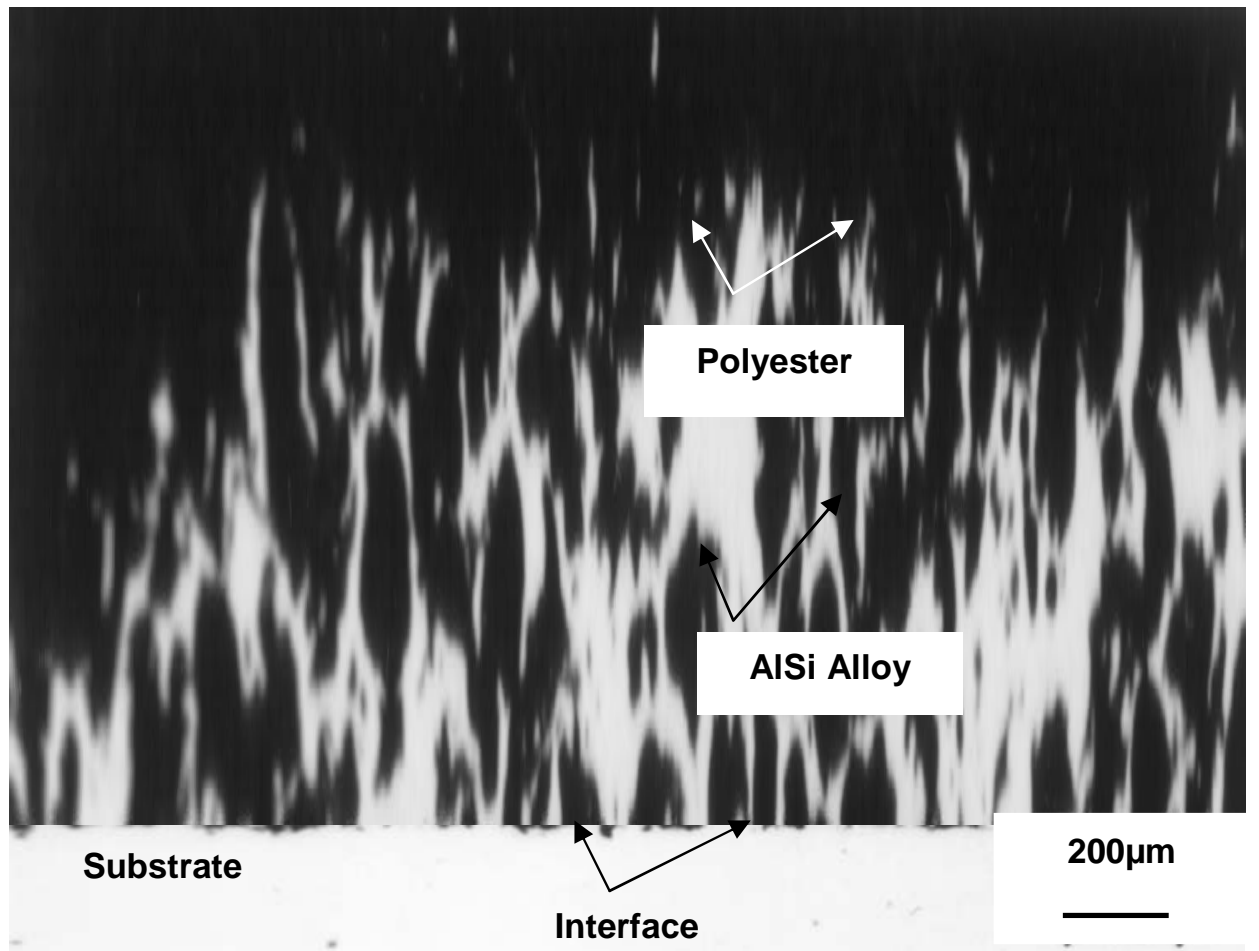

Figure 3 - The microstructure of NiAl- polyester coatings deposited with 6 I / min He Slika 3 - Mikrostruktura NiAl- poliester prevlake deponovane sa 6 I / min $\mathrm{He}$

The boundary of the AISi alloy layer bond with the substrate cannot be seen in the photomicrographs, thus indicating a very good bond of the coating and the substrate, which is consistent with the values of tensile bond strentgh. Several places on the interface show a minor part of polyester since it is surrounded by AISi alloy lamellae in the process of deposition. A good preparation of the surface of the substrate resulted in the absence of remains of electocorund of roughening particles in the interface, which had a good adhesion of the coating with the substrate as a result. For this reason, ther are no micro cracks and macro cracks in the interface and there is no separation of the coating layers from the substrate and no coating peeling. Generally, all the layers are uniformly deposited on the substrate with a mesh structure. In the photomicrographs, the white AISi alloy mesh is marked with black arrows. Unmelted powder particles are not present in the microstructure. In the deposited state, the AISi powder particles are well melted and well-bonded thus making a continuous mesh of the base coating. The continuous mesh of the AISi base is an indicator that the powder particles melted evenly and deposi- 
ted properly in the coating layers. Interwoven with the AISi mesh there is the black polyester mesh marked with white arrows. The polyester particles are deposited in such a way that they are surrounded and closed by the AISi particles that prevent the polyester particles from falling out in the exploitation. Pores in the deposited polyester particles cannot be seen in the microphotographs. The absence of visible pores indicates that the deposited layers have a lower content of pores than the value set by the powder manufacturer (3 - 5\%) [15]. The extracted particles of AISi and polyester are not seen in the microstructure. Micro cracks and rough pores cannot be seen through the coating layers, which is consistent with the mechanical properties of the layers. Fig. 3 shows the cross section of the coating with a total thickness of $1.6 \mathrm{~mm}$.

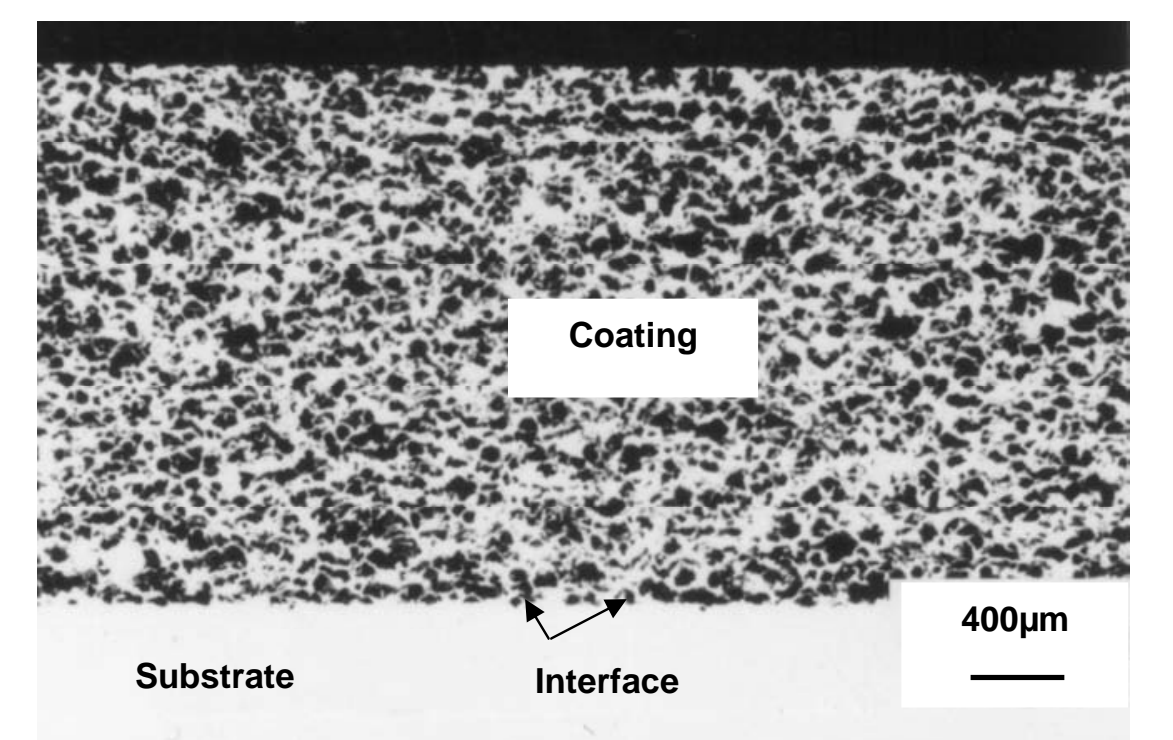

Figure 4 - Microstructure of the NiAl polyester coatings deposited with 12 I/ min He Slika 4 - Mikrostruktura NiAl- polyester prevlake deponovane sa 12 I / min He

Figs. 4 and 5 show the microstructure of the deposited layers with a helium flow of $12 \mathrm{I} / \mathrm{min}$, which showed the best structural and mechanical characteristics. Fig. 4 shows the cross section of the coating with a total thickness of $2.2 \mathrm{~mm}$. The qualitative analysis revealed that the AISi - polyester layers along the intersection of the coating are evenly and continuously deposited on the substrate (Fig. 4). The meshlike structure of the coating has a good bonding with the substrate. Due to the large flow of helium and a higher heat content of the plasma jet, the melted powder particles deformed smoothly and evenly during the collision with the substrate to form a mesh of AISi and polyester (Fig. 5). 
The layers are without the presence of unmelted particles, pores, microcracking and they are denser than the layers deposited with a helium flow rate of $6 \mathrm{I} / \mathrm{min}$. The base structure of the coating is the AISi alloy which, as the metallic phase of the coating, provides: strength, erosion resistance, mutual bonding of the AISi deposited particles and their bonding with the surface substrate. The AISi alloy mesh is white marked with black arrows. The polyester phase is black surrounded and sealed with a metal mesh which is marked with white arrows on the photomicrographs. Fig. 6 shows the fracture morphology of the AISi-polyester coatings deposited with a helium flow of $12 \mathrm{I} / \mathrm{min}$. The photomicrograph shows the AISi alloy fracture in light gray marked with black arrows. The AISi alloy fracture is tough. The microstructure does not show the deposited polyester particles due to weak bonding between the AISi alloy and polyester particles. The cohesive strength between metal grains of the AISi alloy and polyester molecules is low due to different types of material bonding. Poliester is non-metallic polymeric material with a molecular bond, consisting of macromolecules.

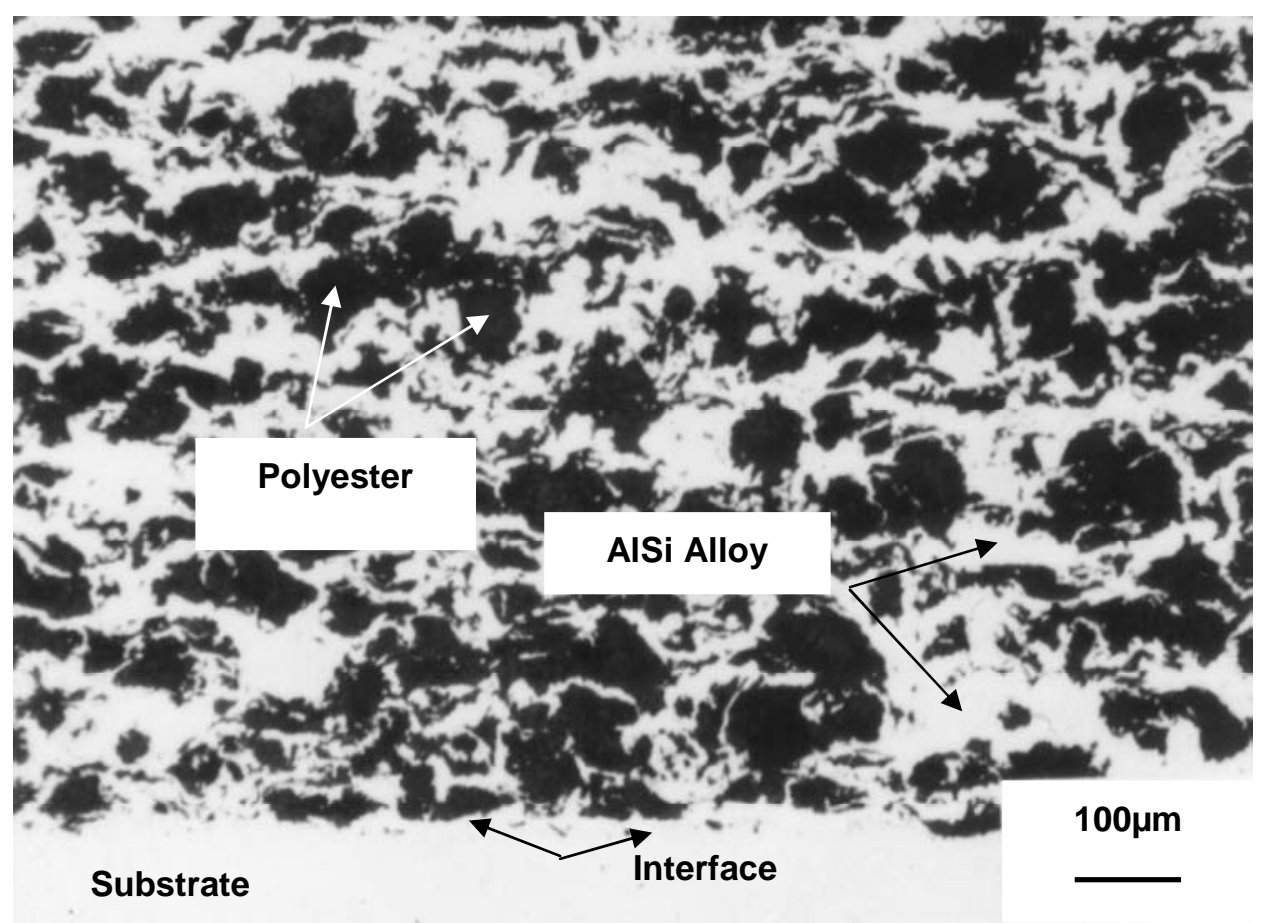

Figure 5 - Microstructure of the NiAl -polyester coatings deposited with 12 I / min He Slika 5 - Mikrostruktura NiAl -poliester prevlake deponovane sa 12 I/ min He 


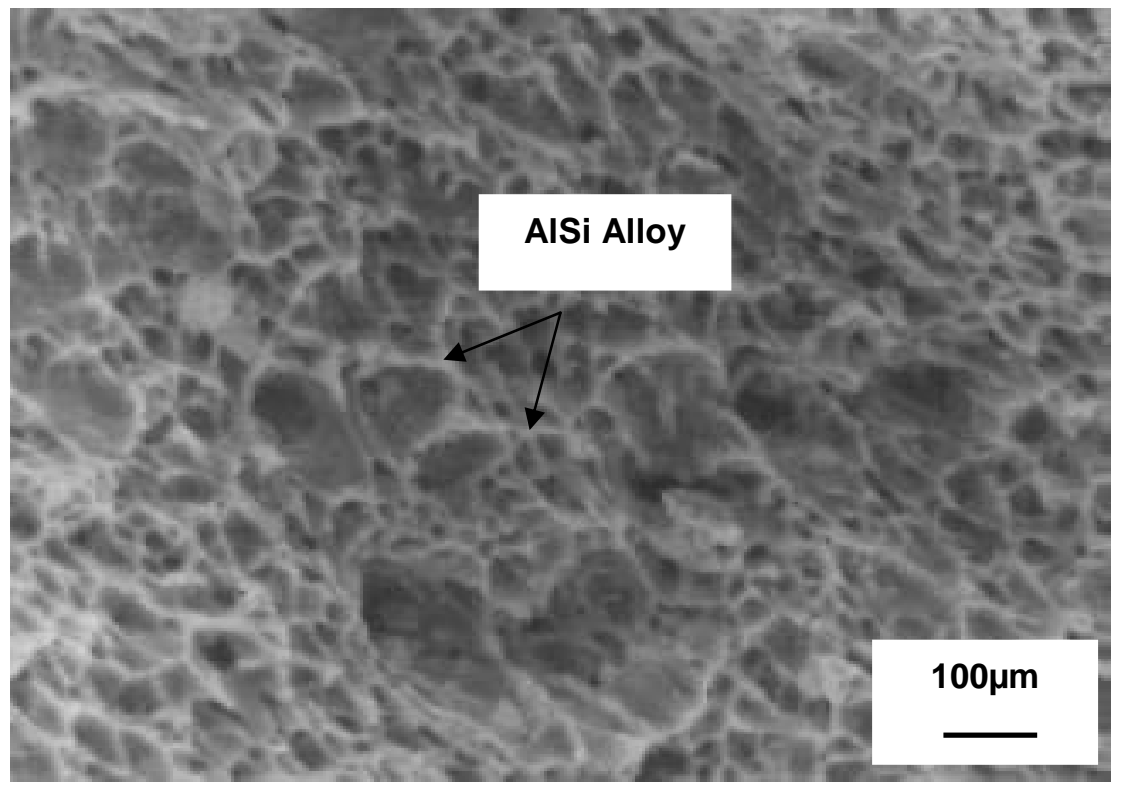

Figure 6 - SEM fracture morphology of the NiAl-polyester coating deposited with 12 I / min $\mathrm{He}$ Slika 6 - (SEM) morfologije loma NiAl-poliester prevlake deponovane sa $12 \mathrm{l} / \mathrm{min} \mathrm{He}$

Because of the weak cohesive strength between the polyester molecules and metal grains, polyester is dislocated and pulled apart from the base during the fracture. The microphotography clearly shows empty places in the AISi alloy base previously filled with polyester. The solidification of the AISi alloy particles resulted in a structure of a solid lubricant. It provides reducing the coating transfer onto the blades, reducing chipping and reducing coating erosion.

\section{Conclusion}

The examination of AISi-polyester coatings deposited with different plasma gas flows of helium has shown that the gas flow affects the mechanical properties and the microstructure.

The layers deposited with a higher plasma gas flow had higher macro hardness values. For both coatings, the macro hardness values were within the prescribed limits.

The tensile strength of the coating bond is directly related to the thickness of the deposited layers and the plasma gas flow. The bond tensile strength decreases with the increase of coating thickness due to a higher share of residual stresses in the deposited layers. The layers deposited 
with a higher plasma gas flow had higher values of tensile bond strength. Both coatings were deposited with the bond strength within the prescribed limits.

The qualitative analysis of the AISi - polyester layers, for both coatings, showed that, along the entire cross-section, the coating were evenly and continuously deposited on the substrates. The interface does not show the particles of electrocorundum from grinding, micro cracks and macro cracks, which enabled the coatings to have good adhesion to substrates.

The microstructures of both coatings showed a uniform structure of AISi alloy and polyester. The AISi-alloy coating base in the solid state has a continuous and uninterrupted mesh.The microstructure of the AISi alloy is white while that of polyester is black. The polyester particles are surrounded and closed by AISi particles thus preventing the polyester particles from falling out during exploitation. All the layers are uniformly deposited on the substrate.

The comparison of the coatings shows that the layers deposited with a higher plasma gas flow are more evenly deposited due to a higher heat content of plasma jets. The coatings are thicker due to a lower share of micro pores and more homogenous along the entire cross-section.

Based on the obtained results, it can be concluded that the plasma gas flow rate can affect the mechanical and structural characteristics of the AISi - polyester soft seal. The application of the AISi-polyester coating on the air labyrinth ring resulted in a higher compressor efficiency with lower fuel consumption. The expected effects have been confirmed after 42-hour engine tests on the test station.

\section{References}

[1] Melcher, K. J., Kypuros, J., Toward a fast-response active turbine tip clearance control., International Symposium on Air Breathing Engines, Cleveland, Ohio, 2003.

[2] Wallis, A. M., Denton, J. D., Demargne, A. A. J., The Control of Shroud Leakage Flows to Reduce Aerodynamic Lossis in a Low Aspect Ratio, Shrouded Axial Flow Turbine, International Gas Turbien and Aeroengine Congress and Exhibition, Munich, Germany, 2000.

[3] Steinetz, B. M., Hendricks, R. C., Munson, J., Advanced Seal Technology Role in Meeting Next Generation Turbine Engine Goals Propulsion and Power Systems First Meeting on Design Principles and Methods for Aircraft Gas Turbine Engines, Toulouse, France,1998.

[4] Novinski, E. R., The Design of thermal sprayed abradable seal coating for gas turbine engines, ITSC 1991, Pittsburg, PA, USA. Ed. Bernecki, T. F., Pub. ASM International, Materials Park, OH, USA. 451- 456.

[5] Borel, M. O., Nicoll, A. R., Schäpfer, H. W., and Schmid, R. K., The wear mechanism occurring in abradable seals of gas turbines, Surf. Coat tech, 39/40 (1989) 117-126. 
[6] Guilemany, J. M., Navarro, J., Lorenzana, C., Vizcaino, S., Miguel, J. M., Tribological behaviour of abradable coatings obtained by atmospheric plasama spraying (APS), ITSC 2001, Singapore. Ed. Berndt, C. C., Khor, K. A., and Lugscheider, E. F., Pub. ASM international, Materials Park, OH-USA.1115 -1118.

[7] Ghasripoor, F., Schmid, R. K.,Dorfman, M., and Russo, L., A Review of Clearance Control Wear Mechanisms for Low Temperature Aluminum Silicon Alloys, ITSC 1998, Nice, France, Ed. Coddet, C. Pub. ASM international, Materials Park, OH -USA.139-144.

[8] Nava, Y., Mutasim, Z., and Coe, M., Abradable Coatngs for Low - Temperature Applications, ITSC 2001, Singapore. Ed. Berndt, C. C., Khor, K. A., and Lugscheider, E. F., Pub. ASM international, Materials Park, OH-USA.119-126.

[9] Maozhong, Y. I., Baiyun, H., and Jiawen, H., Erosion wear behaviour and model of abradable seal coating. Wear 252 (2002) 9 -15.

[10] Yi, M. Z., He, J. W., Huang, B. Y. and Zhou, H., Friction and wear behaviour and abradability of abradable seal coating. Wear 231 (1999) 47-53.

[11] Lim, S. C. and Ashby, M. F., Wear-mechanism maps. Acta Metall, 35(1987) 1-24.

[12] Ashby, M. F. and Lim, S. C., Wear-mechanism maps.Scripta Metallurgica et Materialia 24 (1990) 805-810.

[13] Vencl, A., Mrdak, M., Banjac, M., Correlation of Microstructures and Tribological Properties of Ferrous Coatings Deposited by Atmospheric Plasma Spraying on Al-Si Cast Alloy, Met. Mat. Trans. A, 40, 2, 398-405, 2009.

[14] Tosnar, L., Plasma Sprayed Seal Coatings, Proceedings of the 1st PlasmaTechnik Symposium, Vol. 2, 18 - 20.05.1988, Lucerne, Switzerland, 257-262.

[15] Metco 601 NS Aluminum - Polyester Powder, Technical Bulletin 10 -141, Sulzer Metco, 2000.

[16] Roumilhac, Ph., Coundert, J. F., Leger, J. M., Grimand, A., Fauchais, P., Characterization of a D. C.Spraying Plasma Torch using Optical and Thermal Diagnostics, Proceedings of the 1st Plasma-Technik Symposium , Vol. 1, 18 20.05.1988, Lucerne, Switzerland, 105 -119.

[17] Turbojet Engine - Standard Practices Manual (PN 582005), Pratt \& Whitney, East Hartford, USA, 2002.

PROUČAVANJE KARAKTERISTIKA PLAZMA-SPREJ ZAPTIVNIH ALUMINIJUM-SILICIJUM-POLIESTER PREVLAKA

OBLAST: hemijske tehnologije

VRSTA ČLANKA: originalni naučni članak

\section{Sažetak:}

U studiji je prikazana homologacija plazma-sprej parametara meke abrazivne AlSi-poliester zaptivke radi njene primene na delu kompresora motora TV2-117A. Cilj istraživanja je bilo supstituisanje postojećeg zap- 
tivnog materijala novom klasom materijala da bi se povećao efekat zaptivanja i pod najvećim pritiskom obezbedio protok kroz kompresor vazduha temperature od 100 do $125^{\circ} \mathrm{C}$. Na prstenu vazdušnog lavirinta, kao dela kompresora turbomlaznog motora TV2-117A, primenjen je materijal Metco 601NS i plazma-sprej tehnologija za izradu meke zaptivke. Parametri deponovanja su pažljivo izabrani kako bi se dobila prevlaka sa najboljim karakteristikama u zavisnosti od primene. Pri izboru parametara, kao osnovni parametar, uzet je protok plazma gasa helijuma. Prevlaka sa najboljim mehaničkim i strukturnim karakteristikama deponovana je na prstenu vazdušnog lavirinta da bi se ispitao efekat primene prevlake u sklopu. Mikrostrukture deponovanih slojeva procenjene su na svetlosnom mikroskopu i skening elektronskom mikroskopu (SEM). Mikrostrukturna analiza deponovanih slojeva urađena je u skladu sa standardom Pratt-Whitney. Mehaničke karakteristike prevlaka procenjene su na osnovu ispitivanja makrotvrdoće zaptivnih slojeva metodom HR15Y. Čvrstoće spoja prevlaka ispitane su metodom kidanja na zatezanje. Efekat zaptivanja prstena vazdušnog lavirinta ispitan je u sklopu kompresora motora TV2-117A, na ispitnoj stanici, u trajanju od 42 sata.

Uvod

Razvoj novih generacija turbomlaznih motora uticali su na razvoj novih tehnologija $i$ zaptivnih materijala. Danas se na komponentama kompresora niskog i visokog pritiska primenjuju meke habajuće prevlake koje uzrokuju niskoenergetske uslove trenja i koje su otporne na eroziju. U eksploataciji se meke zaptivne prevlake habaju, umesto da uzrokuju habanje lopatica ili šavova lavirinta. Unapređenje zaptivanja između rotirajućih i stacionarnih delova u aviogasnim turbinama značajno povećava performanse motora kroz poboljšanje termičke efikasnosti. Taj cilj je postignut primenom mekih i tvrdih zaptivki u turbomlaznim motorima. Prah za izradu mekih habajućih prevlaka sastoji se od metalne osnove $i$ dodatne faze koja kontroliše količinu poroznosti u slojevima. Da bi zaptivanje bilo efikasno, neophodno je da se kombinuju svojstva koja su, obično, optimizovana pomoću sastava i odnosa faza u smeši. Plazma-sprej postupak je najpopularniji tehnološki postupak koji se koristi za izradu mekih zaptivki [4]. Tokom rada, materijal prevlake se haba veoma složenim mehanizmima. Pod tim se podrazumevaju: struganje zaptivnog materijala vrhovima lopatica, razmazivanje i lepljenje za lopatice, drobljenje, topljenje, eroziju i oksidaciju [5]. Habajuća zaptivna prevlaka ne sme u eksploataciji da se ošteti i posle struganja lopaticama mora da ostane glatka. Da bi se u eksploataciji dobro habala, prevlaka mora da ima odgovarajuću mekoću, ali i dovoljnu tvrdoću da bi mogla da se odupre eroziji gasa zbog velike brzine gasa $i$ čestica koje se u njemu nalaze. Otpornost na oksidaciju i koroziju i otpornost na termičke šokove takođe su ključni kriterijumi koje habajuća prevlaka mora da zadovolji u sistemu motora. Da bi prevlaka zadovoljila sve te zahteve i omogućila kontrolu curenja između komponenata često se sastoji od dve ili više komponenata. Prevlaku za zapti- 
vanje čine metalna osnova i druga faza kao čvrsto mazivo za kontrolu habanja i poroznosti [6]. Poliester se veoma često koristi kao sredstvo za kontrolu poroznosti i kao čvrsto mazivo koje je okruženo i zatvoreno metalnom osnovom. To pomaže da se smanji prenos prevlake na lopatice i smanji odlamanje, ili da prouzrokuje eroziju prevlake. Prah Metco 601NS mešavina je legure AISi i poliestera, koji je specijalno razvijen za kontrolu zazora mašinskih elemenata. Ispitivanja na delovima avionskih motora potvrdila su da prevlake Metco 601NS imaju visok stepen otpornosti na habanje i da, pritom, ne uzrokuju habanje vrha lopatica kompresora, odličnu otpornost na oksidaciju do $345^{\circ} \mathrm{C}$ i dobru otpornost na termičke šokove. Prah je napravljen tako da se deponuje (APS) atmosferskim plazma-sprej postupkom, uz upotrebu gasova argona/vodonika ili argona/helijuma, kao plazma gasova.

Cilj ove studije je bilo postizanje optimalnih plazma-sprej parametara deponovanja AISi-poliester praha. Istraživanja i rezultati koji su ostvareni u svetu iz te oblasti bili su razlog da prvi put homologujemo $i$ primenimo materijal koji se proizvodi na zapadu na prstenu vazdušnog labirinta dela kompresora turbomlaznog motora TV2-117A koji se proizvodi na istoku. Dakle, cilj istraživanja je bio da se pomoću plazmasprej tehnologije i novog materijala ispita efekat zaptivanja i izvrši supstitucija postojećeg zaptivnog materijala. Od primene nove generacije materijala očekivala se bolja zaptivnost, koja obezbeđuje veći stepen iskorišćenja kompresora uz smanjenu potrošnju goriva. Očekivani efekti su potvrđeni u 42-časovnom ispitivanju motora na ispitnoj stanici.

\section{Detalji eksperimenta}

Za eksperiment je korišćen prah firme Sulzer Metco, sa oznakom Metco 601NS. Taj prah je mešavina legure AlSi i poliestera u odnosu $60 \%$ AlSi i $40 \%$ poliestera, sa temperaturom topljenja od $425^{\circ} \mathrm{C}$ i rasponom granulacije čestica praha od $10 \mu \mathrm{m}$ do $106 \mu \mathrm{m}$ [15]. Zbog niske temperature topljenja praha, primenjen je gas He, koji u kombinaciji Ar/He pravi kraći i gušći mlaz plazme manje specifične entalpije u odnosu na $\mathrm{Ar} / \mathrm{H} 2$. To omogućuje manje sagorevanje $i$ isparavanje komponenata praha. Takođe, gušća plazma, kao što je Ar/He, manje upumpava okolni vazduh, koji umanjuje oksidaciju praha koji se topi $i$ deponuje sa većom gustinom pakovanja u prevlaci [16]. Zbog niske temperature topljenja praha $-425^{\circ} \mathrm{C}$, slojevi su takođe deponovani sa nižom jačinom električne struje i promenljivim protokom plazma-gasa. $U$ eksperimentu je korišćen plazma pištolj SG - 100 firme Plasmadyne, sa odgovarajućim robotizovanim kontrolnim sprej uslovima. Plazma pištolj se sastoji od : katode - tip K 1083 -129, anode - tip A 2083 129, i gas injektora - tip GI 2083 -130. Pri izboru parametara deponovanja, kao osnovni parametar uzet je protok plazma gasa helijuma. Protok gasa helijuma mora da bude optimalan da bi se obezbedilo potpuno topljenje čestica praha i, pri tome, svede na minimum isparavanje komponenata praha. S druge strane, protok plazma gasa treba da obezbedi ravnomerno deponovanje čestica praha koje će obezbediti 
kontinualno deponovanje AISi slojeva u obliku mreže, koja će zatvoriti omekšale $i$ istopljene čestice poliestera i na taj način obezbediti ravnomernu i homogenu strukturu deponovanih slojeva po celom preseku prevlake. $U$ istraživanju su pri deponovanju čestica praha AlSi-poliestera korišćena dva protoka plazma gasa od $6 \mathrm{l} / \mathrm{min}$ He i $12 \mathrm{l} / \mathrm{min} \mathrm{He}$, dok su ostali parametri imali konstantne vrednosti.

Deponovane su tri grupe prevlaka. Prva grupa prevlaka je deponovana sa protokom He od $6 \mathrm{l} / \mathrm{min}$ i $12 \mathrm{l} / \mathrm{min}$, sa debljinama od 0,5 $\mathrm{mm}$, da bi se ustanovio uticaj protoka He na makrotvrdoću i čvrstoću spoja. Druga grupa prevlaka je deponovana sa protokom He od 12 I/min, sa debljinama slojeva od 0,10, 0,20 i 0,30 mm, da bi se ustanovio uticaj debljine prevlaka na čvrstoću spoja. U trećoj grupi su deponovane prevlake sa debljinama od 1,6 do 2,2 mm, koje su propisane za prsten vazdušnog lavirinta, na kojima je ispitana mikrostruktura slojeva. Da bi se analizirala morfologija loma, izvršen je lom prevlake sa najboljim strukturnim i mehaničkim karakteristikama.

Materijal supstrata na koji su deponovani slojevi od AlSi-poliestera bio je od čelika X15Cr13 (AMS 5504). Pre deponovanja nije rađeno predgrevanje supstrata, a površina je hrapavljena belim plemenitim elektrokorundom granulacije od 0,7 do 1,5 mm. Cilj hrapavljenja je bilo uklanjanje tankog oksidnog filma sa površine supstrata da bi se dobila veća čvrstoća spoja prevlake za supstrat.

Ispitivanja i karakterizacija prevlaka rađeni su prema Pratt \& Whitney standardu [17]. Makrotvrdoća prevlaka je merena korišćenjem čelične kugle Rockwell prečnika 12,7 mm i 15 kg opterećenja (HR15y). Makrotvrdoća prevlaka je merena duž slojeva. Da bi se procenila homogenost slojeva merenje je izvršeno u tri oblasti: $u$ sredini i na levom i desnom kraju uzoraka. Uzorci za merenje makrotvrdoće, kao i za analizu mikrostrukture, bili su dimenzija $70 \times 20 \times 1,5 \mathrm{~mm}$. Prikazani rezultati makrotvrdoće su srednje vrednosti većeg broja merenja.

Ispitivanje čvrstoće veze između prevlake i osnove određivano je ispitivanjem na zatezanje. Korišćena su po dva uzorka u paru, dimenzija $\varnothing 25 \times$ $50 \mathrm{~mm}$, od kojih je prevlaka deponovana samo na jedan od njih. Uzorci su spajani pomoću lepka i ostavljani da se vežu učvršćeni u za to namenjen alat. Pri ispitivanju su se koristili adapteri, koji su tako konstruisani da u toku ispitivanja obezbeđuju eliminisanje smicajne sile. Ispitivanja su izvršena na univerzalnoj hidrauličnoj kidalici na sobnoj temperaturi, pri konstantnoj brzini od $1 \mathrm{~mm} / \mathrm{min}$ [17]. Za ispitivanje su korišćena po tri para uzoraka za svaku grupu prevlaka, a od dobijenih vrednosti su izvedene srednje vrednosti.

Mikrostruktura slojeva i kvalitet spoja prevlake i osnove analizirani su pomoću svetlosnog mikroskopa. Morfologija loma prevlake sa najboljim karakteristikama ispitana je na (SEM) skening elektronskom mikroskopu.

\section{Rezultati i diskusija}

Dobijene vrednosti makrotvrdoće i čvrstoće spoja za AlSi-poliester prevlake u zavisnosti od protoka helijuma za debljine slojeva od 0,5 mm prikazane su u tabeli 2. Vrednosti makrotvrdoća slojeva od AISi-poliestera u di- 
rektnoj su vezi sa protokom helijuma. Slojevi deponovani sa protokom helijuma od 6 l/min pokazali su niže vrednosti makrotvrdoće - 72HRy. Prevlake deponovane sa protokom helijuma od $12 \mathrm{l} / \mathrm{min}$ pokazale su vrednost makrotvrdoće od 80HRy. Prosečna razlika makrotvrdoće slojeva iznosi 8HR15y. Vrednosti makrotvrdoće za obe prevlake su u propisanim granicama [15]. Protok helijuma je u manjoj meri uticao na gustinu slojeva i na odnos AISipoliester u deponovanim prevlakama. Slojevi koji su deponovani sa većim protokom helijuma su gušći, što su potvrdila metalografska ispitivanja uzoraka. Takođe, više vrednosti makrotvrdoće AlSi-poliester slojeva deponovanih sa većim protokom helijuma ukazuju na veću kohezionu čvrstoću slojeva, što je potvrđeno rezultatima zatezne čvrstoće spoja.

Prevlake deponovane sa većim protokom helijuma imaju veću zateznu čvrstoću spoja - $13 \mathrm{MPa}$, a slojevi deponovani sa manjim protokom imaju zateznu čvrstoću spoja $10 \mathrm{MPa}$. Tokom testiranja uzoraka, kod svih je do preloma dolazilo duž interfejsa prevlaka/supstrat. To znači da je koheziona čvrstoća AlSi-poliester prevlaka dobra. Za obe prevlake su vrednosti zatezne čvrstoće spoja u propisanim granicama za tu prevlaku [15].

Za drugu grupu prevlaka, koje su deponovane sa debljinama slojeva od 0,10, 0,20 i 0,30 $\mathrm{mm}$ i protokom helijuma od $12 \mathrm{l} / \mathrm{min}$, vrednosti zatezne čvrstoće spoja (slika 1) pokazale su veliki uticaj debljine prevlaka na dobijene vrednosti za čvrstoću spoja. Slojevi najmanje debljine, od 0,1 $\mathrm{mm}$, pokazali su najveću vrednost zatezne čvrstoće spoja od $29 \mathrm{Mpa}$, što se i očekivalo. U toku deponovanja istopljene čestice praha unose sve više napona u slojeve prevlaka sa porastom debljine zbog veće razlike temperature između gornjih slojeva koji se deponuju i donjih slojeva koji su deponovani. Zbog većeg udela zaostalih napona u debljim prevlakama sila kidanja je bila manja. Slojevi debljine $0,2 \mathrm{~mm}$ imaju čvrstoću spoja od $23 \mathrm{MPa}$, a slojevi debljine 0,3 $\mathrm{mm}$ - od 20 MPa. Svi slojevi su imali zatezne čvrstoće spoja veće od propisanih vrednosti [15]. Drugi parametar koji je uticao da se dobiju visoke vrednosti zatezne čvrstoće spoja za sve prevlake je dobra priprema površina supstrata, što je potvrđeno metelografskim ispitivanjem interfejsa između površine supstrata i prevlaka.

Mikrostrukture AISi-poliester slojeva deponovanih sa protokom helijuma od $6 \mathrm{l} / \mathrm{min}$ prikazane su na slici 2 i 3. Obe mikrofotografije pokazuju uniformnu mrežastu strukturu AlSi-poliester slojeva. Granice na interfejsu između supstrata i slojeva AISI-poliester prevlake su izuzetno čiste, što ukazuje na dobru pripremu površine supstrata. Na mikrofotografiji se ne uočava granica spoja slojeva AISi legure sa supstratom. To ukazuje na izuzetno dobru vezu slojeva prevlake i supstrata, što je u saglasnosti sa vrednostima zatezne čvrstoće spoja. Na interfejsu se na nekoliko mesta uočava neznatan deo poliestera pošto je u procesu depozicije okružen lamelama AISi legure. Zbog dobre pripreme površina supstrata na interfejsu nema ostataka čestica elektrokorunda od hrapavljenja, što se odrazilo na dobru adheziju prevlake sa supstratom. Iz navedenog razloga, na interfejsu nema mikro pukotina i makro pukotina, i nema odvajanja slojeva prevlake sa supstrata i ljuštenja prevlake - pilinga. 
Generalno, svi slojevi su ravnomerno deponovani na podloge sa mrežastom strukturom. Na mikrofotografiji je mreža AISi legure bele boje obeležena strelicama crne boje. U mikrostrukturi nema nestopljenih čestica praha. $U$ deponovanom stanju čestice praha AlSi dobro su istopljene i međusobno povezane i prave kontinualnu i neprekidnu mrežu osnove prevlake. Kontinualna mreža AISi osnove je pokazatelj da su se čestice praha ravnomerno topile i pravilno deponovale u slojevima prevlake. Između AlSi mreže postoji mreža poliestera crne boje koja je obeležena belim strelicama.

Čestice poliestera su deponovane tako da su okružene i zatvorene česticama AISi koje u eksploataciji prevlake onemogućuju ispadanje čestica poliestera kao čvrstog sredstva za podmazivanje. Na mikrofotografijama se u deponovanim česticama poliestera ne uočavaju sitne pore. To ukazuje da deponovani slojevi imaju manji sadržaj pora od vrednosti koje propisuje proizvođač praha (3-5) [15]. U mikrostrukturi se ne uočavaju mesta sa izvađenim česticama AISi i poliestera. Kroz slojeve prevlaka se ne uočavaju mikro pukotine $i$ grube pore, što je $u$ skladu sa mehaničkim karakteristikama slojeva.

Na slikama 4 i 5 prikazane su mikrostrukture deponovanih slojeva sa protokom helijuma od $12 \mathrm{l} / \mathrm{min}$ koji su pokazali najbolje strukturne i mehaničke karakteristike. Na slici 4 prikazan je poprečni presek prevlake ukupne debljine od 2,2 $\mathrm{mm}$. Kvalitativna analiza je pokazala da su AISi-poliester slojevi po celom preseku prevlake ravnomerno i bez prekida deponovani na supstratu (slika 4). Struktura prevlake je mrežasta i dobro vezana za supstrat. Zbog većeg protoka helijuma i većeg toplotnog sadržaja mlaza plazme, istopljene čestica praha su se pri sudaru sa supstratom bolje $i$ ravnomernije plastično deformisale formirajući mrežu AISi i poliestera (slika 5). U slojevima nema nestopljenih čestica, pora i mikronaprslina, i gušći su od slojeva deponovanih sa protokom helijuma od $6 \mathrm{l} / \mathrm{min}$.

Osnova strukture prevlake je legura AISi koja, kao metalna faza, prevlaci obezbeđuje: čvrstoću, otpornost na eroziju, međuvezivanje deponovanih čestica AISi i vezivanje sa površinom supstrata. Mreža AISi legure je bele boje, a obeležena je strelicama crne boje. Druga faza poliester, crne boje, okružena je i zatvorena metalnom mrežom, koja je na mikrofotografiji obeležena belim strelicama. Na slici 6 prikazana je mikrofotografija morfologije loma AlSi-poliester prevlake deponovane sa protokom helijuma od $12 \mathrm{l} / \mathrm{min}$. Na mikrofotografiji se vidi prelom legure AISi svetlosive boje koji je obeležen crnim strelicama. Prelom AISi legure je žilav. U mikrostrukturi se ne uočavaju deponovane čestice poliestera zbog slabe uzajamne veze između čestica legure AISi i poliestera. Privlačno dejstvo između metalnih zrna legure AISi i molekula poliestera je slaba zbog različitog tipa veze materijala. Poliester je nemetalni polimerni materijal sa molekulskom vezom, sastavljen od makromolekula. Zbog slabe veze između molekula poliestera i metalnih zrna, pri lomu uzorka došlo je do ispadanja i čupanja poliestera iz osnove. Na mikrofotografiji se jasno vide prazna mesta u osnovi legure AISi koja su bila ispunjena poliesterom. Čestice AISi legure su, zbog očvršćavanja, napravile strukturu prevlake u obliku neprekidne mreže, 
koja zatvara čestice poliestera kao čvrstog sredstva za podmazivanje. To omogućuje da se u eksploataciji smanje prenos prevlake na lopatice i odlamanje ili da prouzrokuje eroziju prevlake.

\section{Zaključak}

Ispitivanje AISi-poliester prevlaka deponovanih sa različitim protokom plazma gasa helijuma pokazalo je da protok gasa utiče na mehanička svojstava i mikrostrukture. Slojevi deponovani sa većim protokom plazma gasa imali su veće vrednosti makrotvrdoće. Za obe prevlake su vrednosti makrotvrdoće bile u propisanim granicama.

Zatezna čvrstoća spoja prevlaka je u direktnoj vezi sa debljinama deponovanih slojeva i sa protokom plazma gasa. Zatezna čvrstoća spoja opada sa porastom debljine prevlaka zbog većeg udela zaostalih napona u deponovanim slojevima. Slojevi koji su deponovani sa većim protokom plazma gasa imali su veće vrednosti zatezne čvrstoće spoja. Obe prevlake su deponovane sa čvrstoćama spoja u propisanim granicama.

Kvalitativna analiza AISi-poliester slojeva, za obe prevlake, pokazala je da su po celom preseku prevlake ravnomerno i bez prekida deponovane na supstratima. Na interfejsu nema čestica elektrokorunda od hrapavljenja, mikro pukotina i makro pukotine, što je omogućilo da prevlake imaju dobru adheziju sa supstratima.

Mikrostrukture obe prevlake su pokazale uniformnu strukturu AISi legure i poliestera. Osnova prevlake od AISi legure u čvrstom stanju ima kontinualnu i neprekidnu mrežu. Mikrostruktura AISi legure je bele, a poliestera crne boje. Čestice poliestera su okružene i zatvorene česticama AISi, koje u eksploataciji prevlake onemogućuju ispadanje čestica poliestera. Svi slojevi su ravnomerno deponovani na podloge.

Poređenjem prevlaka, slojevi deponovani sa većim protokom plazma gasa, zbog većeg toplotnog sadržaja mlaza plazme, ravnomernije su deponovani. Prevlake su gušće zbog manjeg udela mikro pora i homogenije su po celom preseku prevlaka.

Na osnovu dobijenih rezultata, može se zaključiti da protokom plazma gasa može da se utiče na mehaničke i strukturne karakteristike meke zaptivke AlSi-poliester.

Primenom AISi-poliester prevlake na čauri vazdušnog lavirinta postignut je veći stepen iskorišćenja kompresora uz smanjenu potrošnju goriva. Očekivani efekti su potvrđeni 42-časovnim ispitivanjem motora na ispitnoj stanici.

Ključne reči: atmosferski plazma sprej (APS), zaptivka, mikrostruktura, interfejs, makrotvrdoća, čvrstoća spoja.

Datum prijema članka: 22. 12. 2011.

Datum dostavljanja ispravki rukopisa: 28. 12. 2011.

Datum konačnog prihvatanja članka za objavljivanje: 29. 12. 2011. 